\title{
Correspondence
}

CHINA \& WTO ReV. 2021:1; 171-184

http://dx.doi.org/10.14330/cwr.2021.7.1.08

pISSN $2383-8221 \cdot$ elSSN $2384-4388$

China and WTO Review

\section{Treaty Interpretation in the China Rare Earths Case: A Criticism of Textualism}

\author{
Farheen Ahmad* \& Anmolam**
}

Today, as fragmentation of international law has become a reality, the Dispute Settlement Body of the WTO, being one the most essential adjudicatory bodies, has often been criticized for its overly-textualist approach to interpretation and use of the Vienna Convention on the Law of Treaties (VCLT). This commentary analyses the decision rendered by the Dispute Settlement Body in the China-Rare Earths Case. It explains how the textualist reading given by the Appellate Body could not look into the corresponding GATT regulation, while interpreting the Accession Protocol of China. It argues that this erroneous decision is a result of the DSB's reliance on textualism through the use of Article 31 of the VCLT. It looks into the travaux préparatoires of Article 31 of the VCLT to argue that the concerns raised during the Vienna Conference are still relevant and get reflected even today in the decisionmaking in the China-Rare Earths case.

Keywords: WTO Dispute Settlement Body, China-Rare Earths, VCLT, Textualism, WTO

\section{Introduction}

The Dispute Settlement Body (DSB) of the World Trade Organization (WTO) has been extensively studied and acclaimed for producing a significant amount of

* Ph.D. candidate in International Law at South Asian University, New Delhi, India. LL.M. (South Asian U.). ORCID: https://orcid.org/0000-0002-4943-4833. The author may be contacted at: farheenahmad@gmail.com/Address: 817, Akbar Bhawan, Chanakyapuri, New Delhi-110021 India.

** Attorney-at-Law. LL.M. (South Asian U.). The author may be contacted at: lawyer.anmolam@ gmail.com/Address: Parijat House, Behind Rani Kothi, Williamstown, Deoghar: 814112 India.

All the websites cited in the article were last visited on February 1, 2021. 
jurisprudence on interpretation. It generously makes use of the customary rules of treaty interpretation found in Articles 31 and 32 of the Vienna Convention on the Law of Treaties (VCLT). ${ }^{1}$ Nevertheless, at the same time, the DSB has also been very often criticized for its excessively mechanical method employed in the process of interpretation. ${ }^{2}$ In its application of Articles 31 and 32 of the VCLT, which define the basic rule of interpretation, the DSB has been accused of using the means robotically. ${ }^{3}$ Article 3.2 of the Dispute Settlement Understanding asserts that the purpose of the dispute settlement system is to preserve as well as clarify the existing provisions of the WTO Agreements. ${ }^{4}$ Resultantly, while some have lauded the approach of the WTO as a prerequisite to maintaining predictability, legal certainty and security in the decision-making system, ${ }^{5}$ others argue for a departure from strict 'textualism' to integrate purpose and policy-making in interpretation. $^{6}$

This research proposes to view the extensive reliance on textualism as a byproduct of the failure on the part of the Vienna Conference on Law of Treaties to assimilate diverging views on interpretation techniques. Albeit the WTO DSB has viewed international trade law as part and parcel of the larger international law and justice project, in the present case of China-Rare Earths, ${ }^{7}$ it falls short of the same. In this case, wherein the relationship between the WTO Agreements and Accession Protocols was discussed, the Appellate Body (AB) missed an opportunity to reconcile existing problems relating to fragmentation and selective approach to treaty interpretation. This paper is composed of seven parts including Introduction and Conclusion. Part two will address the facts of the case. Part three will examine the AP decision. Part four will look into contrary views. Part five will analyze an alternative perspective for the AP. Part six will review the adopting process of VCLT in relation to treaty interpretation.

\section{Facts of the Case}

In China-Rare Earths, the Complainants (US, EU and Japan) challenged China's imposition of export duties on 58 rare earth products, 15 tungsten products, and 9 molybdenum products. ${ }^{8}$ Before the Panel, the complainants had claimed that: "The measures of China in respect of export duties on rare earths, tungsten, and molybdenum, were inconsistent with China's obligations under Paragraph 11.3 of 
Part I of the Protocol on the Accession of the People's Republic of China to the WTO (CAP)." Paragraph 11.3 requires that China shall eliminate all taxes and charges applied to exports. In its defence, China invoked the general exceptions of Article XX of the GATT 1994 to defend a potential violation of Paragraph 11.3 of China's Accession Protocol and argued that the export duties on rare earths, tungsten, and molybdenum were justified under Article XX(b) and (g) of the GATT 1994. ${ }^{10}$ The Panel found that Chinese measures were inconsistent with its obligation under Paragraph 11.3 of the CAP. ${ }^{11}$ It also found that China could not justify its measures as the obligation in Paragraph 11.3 of CAP was not subject to the general exceptions in Article XX of the GATT $1994 .^{12}$

China appealed against these in light of specific issues of law and legal interpretation. It argued that they were being denied measures to promote their fundamental non-trade interests recognized by the WTO Agreement. ${ }^{13}$ Prior to the Panel, China had argued that Para 11.3 of the CAP was an integral part of the GATT 1994. For this it gave the following two reasons:

First, under Paragraph 1.2 of CAP, CAP is an integral part of the WTO Agreement. ${ }^{14}$ This "WTO Agreement" has to be read as a whole to include not only the Marrakesh Agreement, but also the other Multilateral Trade Agreements annexed to it. It means that if the context is seen as such, "China's Accession Protocol must be treated as an integral part of the WTO Agreement as a whole" since the term the "WTO Agreement" had been used in whole in other parts of CAP such as Article 1.1. China noted, in particular, that the Appellate Body (AB) interpreted the same term in the introductory clause of Paragraph 5.1 in China Publications and Audiovisual Products as referring to the WTO Agreement as a whole. $^{15}$

Second, China also relied upon Article XII.1 of the Marrakesh Agreement which states that a "State ... may accede to this Agreement, on terms to be agreed between it and the WTO and that such accession shall apply to this Agreement and the Multilateral Trade Agreements annexed thereto." ${ }^{, 16}$ They claimed that the terms of the CAP must apply to Multilateral Trade Agreements, i.e., the GATT $1994 .{ }^{17}$

\section{The Appellate Body Decision}

The AB found that "the term "such accession" in the second sentence of Article 
XII:1 refers to the legal act of acceding to the Marrakesh Agreement specified in the first sentence." ${ }^{, 18}$ In particular, the second sentence indicates that the legal act of accession must be operative with respect to the entire package of the WTO rights and obligations as set out in the Marrakesh Agreement and the Multilateral Trade Agreements annexed to it. ${ }^{19}$ In the Appellate Body's understanding, this does not mean that the legal instrument, i.e., CAP which embodies the 'terms' of accession must 'apply' to or somehow be directly incorporated into these Agreements. ${ }^{20}$

It also said that: "Article XII:1 itself does not speak to the question of the specific relationship between individual provisions of an accession protocol and individual provisions of the Marrakesh Agreement and the Multilateral Trade Agreements." ${ }^{21}$

Turning to Paragraph 1.2 of the CAP, the AB noted the finding of the Panel wherein it had said that "Paragraph 1.2 is to make China's Accession Protocol, in its entirety, an "integral part" of the Marrakesh Agreement, and not that, in addition, the individual provisions of the CAP are also integral parts of Multilateral Trade Agreements annexed to the Marrakesh Agreement. ${ }^{, 22}$ After looking into the dictionary meaning of what 'integral' might imply and the immediate context of Paragraph 1.2, i.e., Paragraphs 1.1 and 1.3, the AB said that they did not consider that determining the scope of the term the "WTO Agreement" in Paragraph 1.2 was dispositive of the key legal question before the Panel. ${ }^{23}$ Thus, for the AB, entering into the specific relationship between individual provisions of China's Accession Protocol and the individual provisions of the Marrakesh Agreement and the Multilateral Trade Agreements was not necessary. ${ }^{24}$

On the other hand, as a "result of Paragraph 1.2 of CAP therefore, the Marrakesh Agreement, the Multilateral Trade Agreements, and CAP together form one package of rights and obligations that must be read in conjunction. ${ }^{25}$ It also said:

[T]he bridge created by Paragraph 1.2 between the protocol provisions and the existing package of rights and obligations under the WTO legal framework, however, is of a general nature. The fact that such a bridge exists does not in itself answer the question as to how individual provisions in China's Accession Protocol are related or linked to individual provisions of the other WTO agreements. More specifically, this bridge does not dispense with the need to analyze, on a case-by-case basis, the specific relationship between an individual provision in the Protocol, on the one hand, and provisions of the 
Marrakesh Agreement and the Multilateral Trade Agreements, on the other hand. ${ }^{26}$

It concluded that in principle, different types of provisions and circumstances might lead to such a determination. For example, Article 3 of the TRIMs Agreement expressly provides that all exceptions under the GATT 1994 shall appropriately apply to the provisions of this Agreement, but on the other hand, Article XX of the GATT 1994 was found by the Appellate Body to be inapplicable to the Agreement on Technical Barriers to Trade (hereinafter TBT Agreement). ${ }^{27}$ Thus, in its view such inquiries must be made on a case by case basis by a thorough analysis of the relevant provisions based on of the customary rules of treaty interpretation and the circumstances of the dispute which would include the text of the relevant provision in CAP and after taking into account its context, including that provided by the Protocol itself and by relevant provisions of the Accession Working Party Report, and by the agreements in the WTO legal framework. ${ }^{28}$ This analysis must also take into account the overall architecture of the WTO system as a single package of rights and obligations. Also, any other relevant interpretative elements must be applied to the circumstances of each dispute, including the measure at issue and the nature of the alleged violation. ${ }^{29}$ Subsequently, the $\mathrm{AB}$ found that since the ruling in China-Raw Materials, which were based purely on the text and context of Paragraph 11.3, had not been challenged nor could China substantially prove its claim of the intrinsic relationship between CAP and the GATT Agreements, the Chinese appeal did not hold. ${ }^{30}$

The AB finally held that China could not avail the benefit of GATT XX $(\mathrm{g})$ exceptions relating to the conservation of exhaustible natural since China could not ably demonstrate if the export quotas in fact promoted conservation, or were a disguised means to protect domestic purchasers.

\section{Contrary Views}

Now, it may be interesting to look at the dissenting opinion of one of the Panelists in China-Rare Earths. The panelist proposed the fact that since the WTO Agreement is a "Single Undertaking" - that is, a single treaty for which there are no reservations and where all WTO provisions are generally, simultaneously and cumulatively applicable and since any acceding party can be taken to the DSB due 
to violation of a provision in the Protocol, this indicates that all parties consider that the provision is an integral part of one of the WTO covered agreements. ${ }^{32}$ Suppose a Protocol adds to the obligations of a party, but does not mention the exact relationship between itself and the parent treaty. In that case, this is not completely dispositive of the fact that the omission was intended to eliminate the application of a provision from the parent treaty. ${ }^{33}$ This can be verified from the fact that the Accession Protocol does not speak of the MFN provision either, but surely no one would contend that it is not applicable. ${ }^{34}$ Moreover, the Panelist was of the view that the defences under GATT 1994 are automatically applicable as they "strike a balance between the policy space governments enjoy to pursue legitimate objectives and their obligations." 35

Scholars have been also critical of the approach of the AB in this case as many felt that the $\mathrm{AB}$ had been given a chance after China-Raw Materials to redeem itself. Qin notes the shift in opinion of the parties since China-Raw Materials to China-Rare Earths where a number of third parties, as well as a panelist, were reconsidering the approach of the $\mathrm{AB} .{ }^{36}$ Bond and Trachtman observe that the AB's argument on inutility of other provisions does not hold good as a number of provisions in the CAP are already inutile. ${ }^{37}$ Korea, as a third-party remarked that if the interpretation was leading towards ambiguity, then recourse should be made to preparatory works of the accession negotiation. ${ }^{38}$ They, therefore, argue for broader context, object, and purpose as interpretive bases under Article 31 of the VCLT for determining the relationship between Article 11.3 of the CAP and the exceptions contained in the GATT $1994{ }^{39}$

Matsushita and Schoenbaum call the decision of the AB as contrary to the principles of treaty interpretation. Both claim that since the Accession Protocol was signed first and on its basis, China entered into the WTO system; the GATT is a subsequent agreement; and as per the rule of treaty interpretation, the GATT provisions apply explicitly. ${ }^{40}$

\section{An Alternative Perspective for the Appellate Body}

Scholars suggest the WTO AB to self-correct itself. ${ }^{41}$ Before trying to correct itself, however, the $\mathrm{AB}$ must come to terms with the fact that problems which are cropping up today can be seen in the light of the history of practice of judicial 
interpretation. In the year 1968-69, when the text of the VCLT was being drafted, the modes of treaty interpretation were extensively debated. Those issues raised at that time are yet unresolved and even today put adjudicatory bodies like the WTO in a fix leading to further fragmentation of international law. This concern has historically been discussed by the scholars and state party representatives as well, and the travaux préparatoires of the VCLT is a testimony to it. A relook at the problems and an integrative approach can help balance out these issues.

\section{A Criticism of Textualism}

At the 31st meeting of the Committee of the Whole at the Vienna Conference on Law of Treaties in 1968, Myers McDougal introduced an alternative to the text of Articles 27 and 28 (the existing Articles 31 and 32) drafted by the International Law Commission (ILC). These articles, pertaining to General Rule of Interpretation and Supplementary Rule of Interpretation, respectively, had been drafted by the ILC in their work towards codification of the law of treaties. The US delegation, of which McDougal was a part, introduced an amendment to these articles by presenting a single combined article in order to do away with the "over-rigid and unnecessarily restrictive" ${ }^{, 42}$ draft of the ILC. This amendment was rejected by 66 votes to 8 , with 10 abstentions. ${ }^{43}$

However, the substance of the debate hold true even today. The normative framework followed by the ILC pointed primarily towards the textual approach. It comprised of the principle of good faith wherein the starting point adopted in Article 27 was the text of the treaty. ${ }^{44}$ This text comprised of the ordinary meaning given to the terms of the treaty along with the context and its object and purpose. Paragraph 2 which enumerated the context listed the intrinsic means of interpretation such as any agreement relating to the treaty which was made between all the parties in connection with the conclusion of the treaty and any relevant rule of international law applicable between the parties. ${ }^{45}$ Paragraph 3 listed the extrinsic factors such as subsequent agreement, subsequent practice and any other that if the parties intended a special meaning to a term then it has to be established. The burden of proof lies on the party invoking the special meaning. ${ }^{46}$ These paragraphs constituted a single rule and created no hierarchy. ${ }^{47}$ However, there was an inherent hierarchy between Articles 27 and 28. Article 28 allowed 
recourse to preparatory material including the preparatory work of the treaty and the circumstances of its conclusion, "only in order to confirm the meaning" determined through Article 27 or in case of ambiguity, obscurity, or manifestly absurd or unreasonable result. The ILC justified that the "word "supplementary" emphasizes that Article 28 does not provide for alternative, autonomous, means of interpretation but only for means to aid an interpretation governed by the principles contained in Article 27., ${ }^{48}$

It was on the point of this apparent hierarchy and the rigid textual approach of the Commission's draft that launched the debate. The point of contention raised by the American delegation was that the context did not permit to include factual circumstance relating to the conclusion of the treaty. The object and purpose did not locate the intention of the parties, but only referred to words intrinsic to the text. ${ }^{49}$ In order to establish his claims, McDougal advanced the following three arguments. Firstly, he argued that such a rigid structure as presented by the ILC had never been part of international law and existing principles of interpretation had mostly acted as permissive guidelines. ${ }^{50}$ This "arbitrary presumption" was taken as "established law" only because of the approval by L'Institut de Droit International and the International Court of Justice. ${ }^{51}$ Secondly, he contended that words were meaningless if treated separately from the circumstances in which they were adopted. The ordinary meaning is a "mere indication" of the common intention of the parties. ${ }^{52}$ References to 'context' and "object and purpose" will not remedy the arbitrariness of ordinary meaning as 'context' has been restrictively defined to include mere text. ${ }^{53}$ Towards this end, he approved of the Harvard Research which stated that:

The historical background of a treaty, travaux preparatoires, the circumstances of the parties at the time the treaty was entered into, the change in these circumstances sought to be effected, the subsequent conduct of the parties in applying the provisions of the treaty, and the conditions prevailing at the time interpretation is being made, are to be considered in connection with the general purpose which the treaty is intended to serve. $^{54}$

Thirdly, he reasoned that the hierarchy between Articles 27 and 28, is an "obscurantist tautology." The determination of the question whether a text requires interpretation or not, is in itself an interpretation and at the same time 
the grounds for determining this are not known. McDougal invoked the doctrine of petitio principii of Vattel, which means that "it is not permissible to interpret what has no need of interpretation., ${ }^{, 56}$ The doctrine begs the question whether the words are clear or not, which is a subjective matter and may be evident to one person but not to the other. Thus, this argument is often resorted to show that there was no need to determine the intention of the parties. Finally, he argued that the restrictions imposed upon the use of preparatory work are not established 'dicta' and courts have been using it unapologetically. ${ }^{57}$ Due to these reasons, McDougal thought of the draft by ILC as unworkable. ${ }^{58}$ This, he substantiated, was quite evident from the presence of the Expert Consultant at the Conference whose task was to explain to the members the meanings of the terms used by the Commission. ${ }^{59}$ If the text could be conclusive of the intention of the parties, the presence of an expert was indeed not needed. The imposition of ordinary meaning over the common intention of the parties would be unjustifiable. ${ }^{60}$ Thus, while the text could be the "point of departure" it could not be the "end of inquiry."

One may contend that some standard rules of interpretation are essential in the area of international law due to not only the variety of bodies, but also the democratized nature of bodies which need to interpret and implement documents ranging from statements to treaties. This would allow states to expect at least a general scheme of interpretation and be better prepared in any case. In China-Rare Earths, however, the DSB has very literally read the requirements of Articles 31 and 32, thereby building a strictly hierarchical structure "even within the means" of Article 31. This becomes conspicuous when it fails to read even the GATT 1994 as part of the context. Had it indulged into the larger question of the objective of trade liberalization $v i s-\grave{a}$-vis environmental protection and conservation, a different decision could have emerged.

\section{Conclusion}

In this regard, some observations may be made. Firstly, as has been contented, it is unfortunate to witness the DSB interpreting Articles 31 and 32 as it is, i.e., quite literally, which creates a hierarchy in the process. It fails to go beyond its textual understanding of what a tool of interpretation may mean. This reminds one of the "obscurantist tautology." Does the tool of interpretation require an interpretation? 
Could the AB have read the Accession Protocol as a subsequent agreement, as claimed by China?

Secondly, despite the ILC's effort to balance the textual and teleological understanding, which does show some result, dispute settlement bodies take resort to the means in Articles 31 and 32 in order to showcase their decisions as objective in order to eliminate any prospective criticism of subjective bias towards the interpreter. However, one cannot guarantee that the interpreter acts in a vacuum, devoid of any subjective notions. The principles of interpretation have potential flexibility to give maneuvering scope to the interpreter. After all, one cannot deny the overlaps between decision-making and policy considerations. Quite ironically, notwithstanding the subjectivity inherent in the process of interpretation, "any meaning derived" at the end is professed to be objective. This is where the criticism of the use of ordinary meaning separated from other surrounding circumstances as pointed out in the Vienna Conference becomes noticeable. Words ought to be only read in the context in which they were intended. This is critical in the WTO case where use of dictionaries is celebrated.

Thirdly, the WTO practice is an example of the apprehension highlighted by McDougal. It is argued here that the ordinary meaning construct has led to one particular reading of the law, not necessarily the commonly intended meaning. In fact, the $\mathrm{AB}$ in China-Rare Earths did not look through the preparatory work despite the ambiguity around the law. Therefore, in every scenario, it is incumbent upon the DSB to comprehensively and holistically approach interpretation and application of law.

Fourthly, a holistic approach would not only allow the body to evade criticism, but also help preserve the unity of international law. A strictly textualist approach leads to further fragmentation of international law. The applicability of the VCLT to each branch of international law means that a flexible approach in interpretation of treaty can evade further fragmentation.

Finally, one cannot say with certainty that the text is the best representative of the intention of the parties. While the text is the starting point, it is only reasonable to look into the preparatory work because it would provide a larger picture of the manner in which a party consents to something. It would be imprudent to deny the role of power politics in law. Determining the intention of the parties is very difficult as a lot would depend on the advantages and benefits they desire vis-à- 
vis the obligations they have to undertake. However, it is a duty of the interpreter to take the words of the parties in good faith and to apply them accordingly, so that the decision best represents the common intention of the parties and is also mindful of the larger purpose of the law.

\section{REFERENCES}

1. Vienna Convention on the Law of Treaties arts. 31-32, May 23, 1969, 1155 U.N.T.S. 331.

2. See, e.g., W. Magnuson, WTO Jurisprudence \& Its Critiques: The Appellate Body's AntiConstitutional Resistance, 51 Harv. Int'L L. J. 121 (2010); H. Horn \& J. Weiler, European Communities - Trade Description of Sardines: Textualism and its Discontent, in THE WTO CASE Law of 2002 (H. Horn \& P. Mavroidis eds., 2005); D. Tarullo, The Hidden Costs of International Dispute Settlement: WTO Review of Domestic Anti-dumping Decisions, 34 L. \& PoL'y INT'L Bus. 124 (2002).

3. F. Ortino, Treaty Interpretation and the WTO AB Report in US - Gambling: A Critique, $9 \mathrm{~J}$. INT'L ECON. L. 117 (2006).

4. Article 3.2 of the Dispute Settlement Understanding states that the dispute settlement system of the WTO is a central element in providing security and predictability to the multilateral trading system.

5. W. Weiss, Security and Predictability under WTO law, 2 World Trade Rev. 183 (2003).

6. J. Pauwelyn, The Role of Public International Law in the WTO: How Far Can We Go?, 95 Aм. J. InT'L L. 577-8 (2001).

7. Appellate Body Report, China - Measures related to the Exportation of Rare Earths, Tungsten, and Molybdenum, WTO Doc. WT/DS431/AB/R (adopted Aug. 7, 2014) [hereinafter Appellate Body Report], available at https://www.wto.org/english/tratop_e/ dispu_e/431_432_433abr_e.pdf.

8. Id. at 16-7.

9. Id. at 18 .

10. Id.

11. $I d$. at $20 \uparrow 1.12$.

12. Id. at 20 1.13.

13. First Written Submission by China, $\uparrow 459$, in Panel Report, China - Measures related to the Exportation of Rare Earths, Tungsten, and Molybdenum, 61, WTO Doc. WT/DS431/R - WT/ DS432/R - WT/DS433/R (adopted Aug. 29, 2014) [hereinafter Panel Report], available at https://www.wto.org/english/tratop_e/dispu_e/cases_e/ds431_e.htm.

14. CAP Paragraph 1.2 reads: "This Protocol (CAP), which shall include the commitments 
referred to in paragraph 342 of the Working Party Report, shall be an integral part of the WTO Agreement."

15. Appellate Body Report, supra note 7, at 30 -2.12.

16. Id. at 5.26 .

17. Id. at 29 - 2.11 .

18. Id. at 95.32 .

19. Id.

20. Id.

21. Id. at 95.34 .

22. Id. at $\uparrow 5.26$, quoting from $₫ 7.93$ of the Panel Report, supra note 13.

23. Id. at 15.49 .

24. Matsushita and Schoenbaum call this a literal interpretation of the relationship between CAP Paragraph 11.3 and the WTO Agreement by the Panel. See Mitsuo Matsushita \& T. Schoenbaum, A Note on the China Rare Earths Case, in Emerging Issues in Sustainable Development 84 (Mitsuo Matsushita \& T. Schoenbaum eds., 2016).

25. Appellate Body Report, supra note 7, at 9.49 .

26. Id. at 95.50 .

27. Id. at 95.56 .

28. Id. at 95.74 .

29. Id. at 95.74 .

30. Id. at $9.63-5.70$.

31. For details, see Matsushita \& Schoenbaum, supra note 24, at 90-1.

32. Panel Report, supra note 7, at $97.124-7.125$

33. Id. at 7.129-7.135. Elisa Baroncini also contends that in order to attribute meaning to the silence of Paragraph 11.3, the principle of permanent sovereignty over natural resources should be used as China would never knowingly abdicate such a remedy. See E. Baroncini, The China-Rare Earths WTO Dispute: A Precious Chance to Revise The China-Raw Materials Conclusions on the Applicability of GATT Article XX to China's WTO Accession Protocol, 4 Cuadernos De Derecho Transnacional 66 (2012).

34. Panel Report, supra note 7, at $\mathbf{9} 7.135$

35. Id. at 7.137

36. Julia Qin, Judicial Authority in WTO Law: A Commentary on the Appellate Body's Decision in China - Rare Earths, 13 CHInese J. InT'L L. 641 (2014).

37. E. Bond \& J. Trachtman, China - Rare Earths: Export Restrictions and the Limits of Textual Interpretation, 15 World Trade Rev. 197 (2014).

38. Appellate Body Report, supra note 7, at $₫$ 2.7.7.

39. Bond \& Trachtman, supra note 37, at 197.

40. Matsushita \& Schoenbaum, supra note 24, at 94.

41. Qin, supra note 36, at 649. 
42. M. McDougal, Vienna Conference on the Law of Treaties, 62 Aм. J. INT'L L. 1021 (1968), available at $\mathrm{http}: / /$ digitalcommons.law.yale.edu/fss_papers/2576.

43. UN Conference on Law of Treaties, First Session, UN Doc. A/CONF.39/C.1/SR.33, 185 (1969). [hereinafter First Session]

44. UN Conference on the Law of Treaties, First and Second sessions, UN Doc. A/CONF.39/11/ Add.2, 37 (Vienna, 26 March-24 May 1968 and 9 April- 22 May 1969).

45. First Session, supra note 43, at 180.

46. Report of the International Law Commission on the work of its 18th session, U.N. Doc. A/ 6309/Kev. at 53 (1966).

47. Id.

48. Id. at 54 .

49. See The draft proposed by McDougal, U.N. Doc. A/CONF.39/C.1/L.156.

50. McDougal, supra note 42, at 1022.

51. M. McDougal, The International Law Commission's Draft Articles Upon Interpretation: Textuality Redivivus, 61 Ам. J. InT'L L. 992 (1967).

52. McDougal, supra note 42, at 1023. [Emphasis added]

53. McDougal, supra note 51, at 993.

54. Id. at 999-1000. At the same time, he was critical of the Harvard Research as it failed to provide "a comprehensive and systematic set of principles of content and procedure."

55. McDougal, supra note 42, at 1023.

56. First Session, supra note 43, 167 \ 41.

57. McDougal, supra note 42, at 1023.

58. First Session, supra note 43, 167 \ 44.

59. Id. at $167,045$.

60. Id. at $167, \llbracket 46$.

61. Id. at $167, \mathbb{1} 41$. 
